\title{
Risk Factors of Vapor Explosion of Molten Slag in Slag Yard for Steelworks
}

\author{
Young-Jae Cho ${ }^{1 \dagger}$, Woojung Park ${ }^{2 \dagger}$, Hong-Sik Yun ${ }^{3 *}$, Hyoung-Uk Yoon ${ }^{3}$ and Sungyool Bong4* \\ ${ }^{1+}$ Disaster Prevention Center, POSCO, Republic of Korea \\ ${ }^{2+}$ Department of Civil \& Environmental Engineering, Worcester Polytechnic Institute (WPI), United States \\ ${ }_{3}^{3}$ Interdisciplinary Program in Crisis, Disaster and Risk Management, Sungkyunkwan University, Republic of Korea \\ ${ }^{4}$ Department of Mechanical Engineering, Worcester Polytechnic Institute (WPI), United States
}

Submission: May 25, 2020; Published: June 04, 2020

*Corresponding author: Sungyool Bong, Department of Mechanical Engineering, Worcester Polytechnic Institute (WPI), Worcester, MA 01609, United States

Hong-Sik Yun, Interdisciplinary Program in Crisis, Disaster and Risk Management, Sungkyunkwan University, Suwon 16419, Republic of Korea

\section{Abstract}

The risk of vapor explosions has always existed in steelworks that deal with a large amount of high-temperature molten slag. Previous studies on vapor explosions caused by the direct contact of high-temperature molten slag with cooling water were mainly focused on nuclear power plants, whereas there is hardly any research on vapor explosions concerning molten slag in steelworks. Therefore, there is a necessity to understand the causes of vapor explosions occurring during the work process at slag yards. This study analyzed risk factors of potential vapor explosions during the work process at slag yards in steelworks and conducted a small-scale experiment based on field conditions. The experiment found the risk factors that cause vapor explosions at the cooling stage and loading stages of the process and found that spontaneous vapor explosions occurred depending on the temperature of cooling water for molten slag and the contained salinity. Thus, it was confirmed that the significant causes of vapor explosions in the steel industry were the salinity of the cooling water concentrated by seawater desalination and high-water temperature at $50^{\circ} \mathrm{C}$ caused by the circulation structure of cooling water.

Keywords: Vapor explosion; Steelworks; Slag yard; Molten slag; Salinity

\section{Introduction}

On November 3, 2017, around 11:24 PM, molten slag $\left(1500^{\circ} \mathrm{C}\right)$ exploded with a thunderous noise, causing a secondary fire in the slag yard of the Pohang Iron and Steel Company (POSCO) located in South Korea. Following this, shock waves destroyed all the windows of a nearby electrical room. This accident occurred when a large amount of vapor generated during the process of cooling molten slag blocked the vision of a payloader driver who was passing through Yard C, as shown in Figure 1. This resulted in a massive collision with the dam border of the slag yard, causing hot molten slag to fall onto the cooling water in a pothole, resulting in a vapor explosion in Figure 2. Figure 3 shows the images of this steelwork vapor explosion.

This accident notified the precautions that should be taken with the process of steelworks slag yards in which large quantities of high-temperature molten slag was simultaneously performed with the cooling process. This revealed only a substantial part of the reoccurring vapor explosions caused by molten slag. Vapor explosions are a physical phenomenon in which explosive boiling occurs when heat contained in molten slag is rapidly converted to gas, and although steel mills make efforts to prevent such a phenomenon, one or more vapor explosion accidents cause fatalities and property damage every year [1-3].

In the past, fundamental studies on vapor explosions were focused on nuclear power plants [4] due to the frequently occurring vapor explosions during the cooling work process in a nuclear reactor, which led to the contact of the melted fuel rods to the cooling water [3]. In the steelwork industry where a large amount of high-temperature molten metal is handled and the direct cooling process is performed, there is always a considerable risk of vapor explosions compared to nuclear power plants [5-7]. 


\section{International Journal of Environmental Sciences \& Natural Resources}

Herein, this study aims to conduct fundamental research required to establish preemptive measures against vapor explosions by finding out risk factors and scientifically

investigating the causes of the molten slag vapor explosions in the steel industry by conducting small-scale experiments.
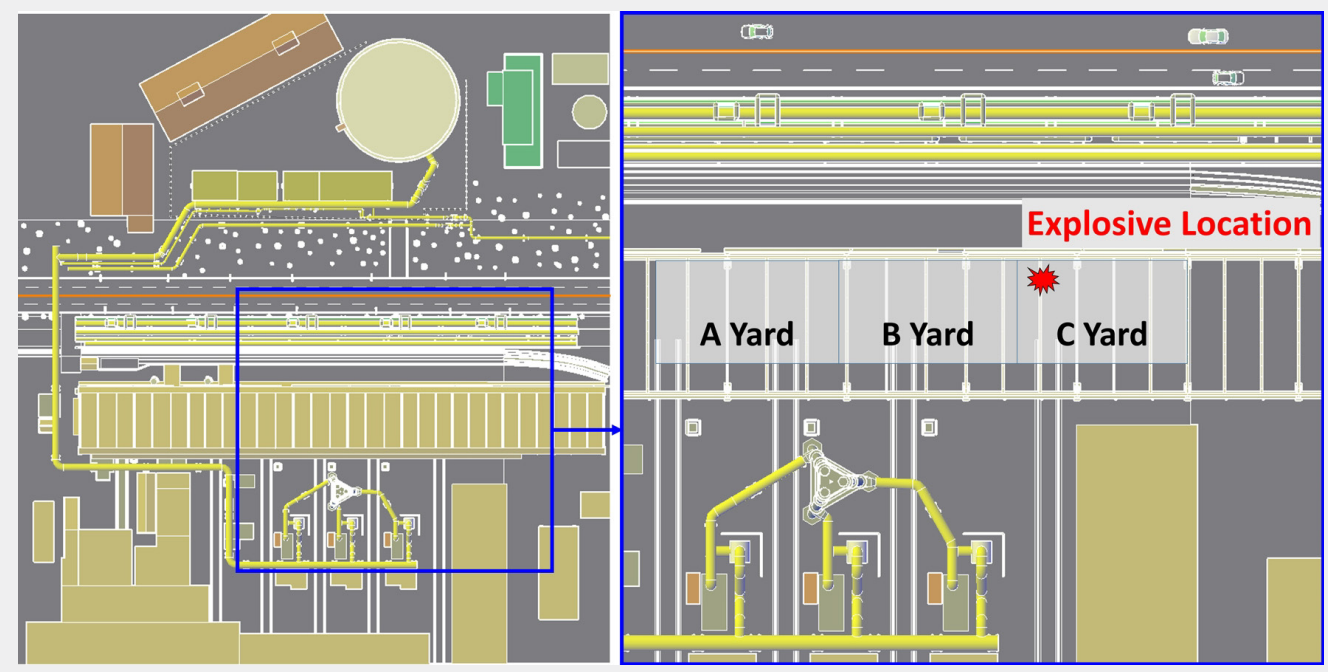

Figure 1: Slag yard workplace accident area.

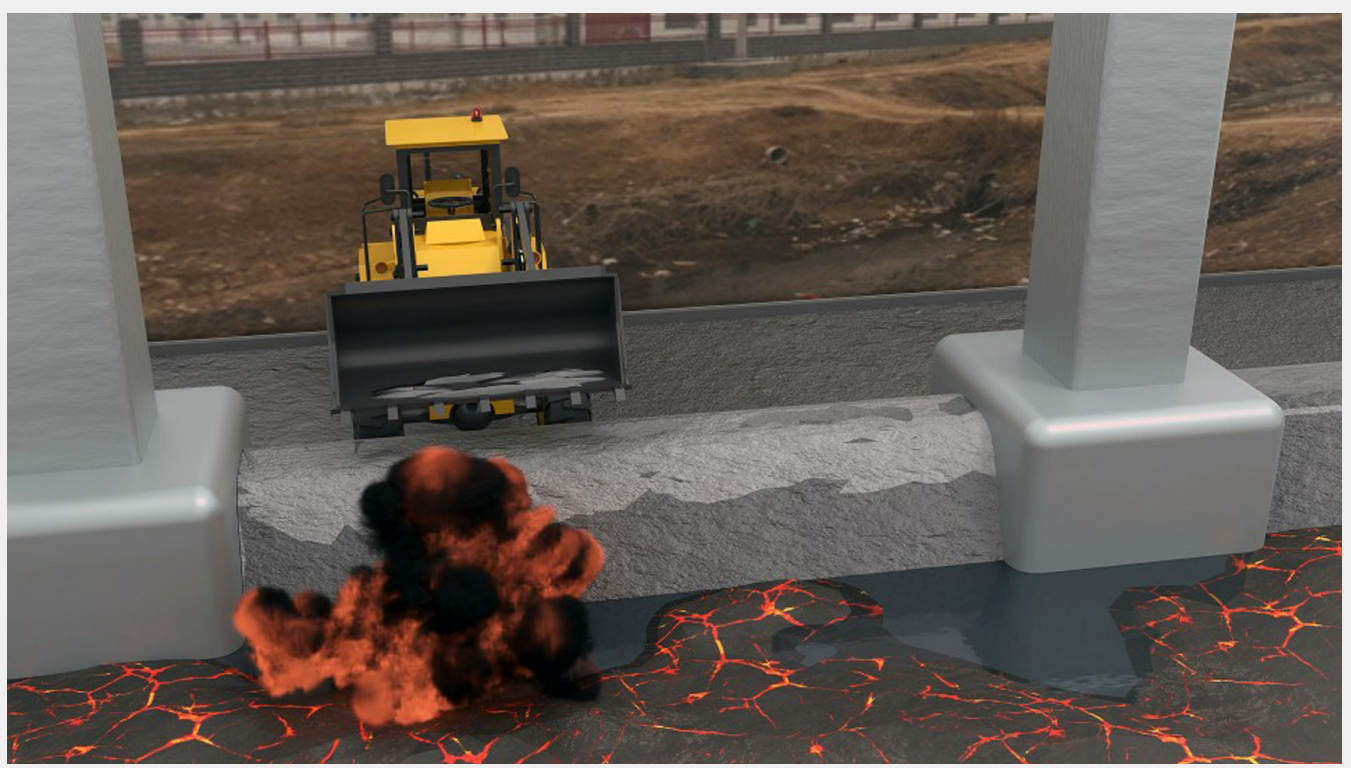

Figure 2: Explosion process reappearance.
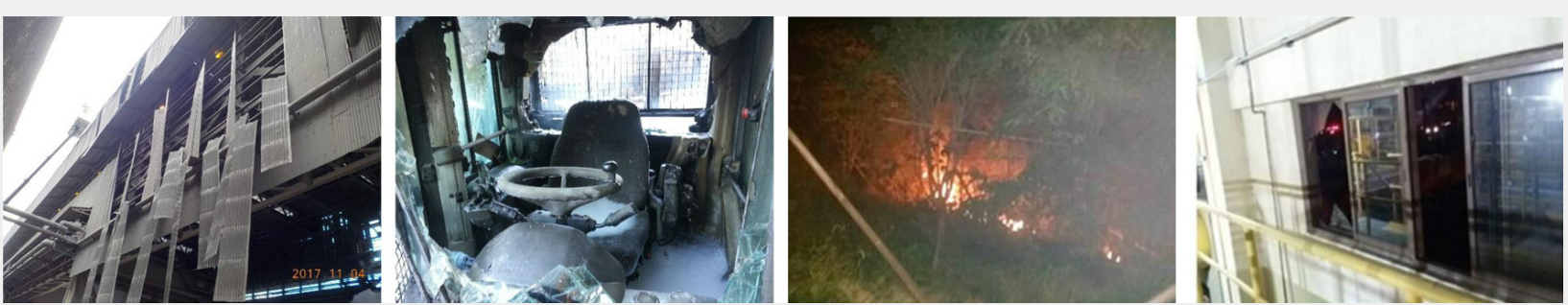

Figure 3: Images of the steelwork vapor explosion (November 3, 2017). 


\section{Experiment}

\section{Experimental plan}

The experiment plan was established based on the past research trends and the analysis of the current state of the slag yard. In order to investigate the causes of vapor explosions of steelworks, molten slag was conducted in the form of small-scale experiments that made it easier to visualize the chain reaction of vapor explosions and understand its relationship with coolant temperature. To create a controlled environment, the molten slag was dropped into three different coolants such as yard coolant, factory fresh water and general tap water to investigate the spontaneous vapor explosion. The molten slag melted in the temperature range of $1300^{\circ} \mathrm{C} \sim 1500^{\circ} \mathrm{C}$ was measured in the skimming process and then dropped in a $100 \mathrm{~g}$ unit. The temperature of the coolant was set in the range from $20^{\circ} \mathrm{C}$ to $80^{\circ} \mathrm{C}$ considering the minimum and maximum temperatures in winter and summer seasons.

\section{Analysis of the slag yard space}

The slag yard of POSCO is a steel-frame structure where the cooling process of molten slag occurs in only $3488 \mathrm{~m}^{2}(109 \mathrm{~m} \times$ $32 \mathrm{~m}$ ) out of $10000 \mathrm{~m}^{2}$. The slag yard is surrounded by pipes and storages handling flammable gas and an electrical room. The details described in Table 1 and Figure 4 show the information of the surrounding environment of the slag yard. Lintz Donawitz Gas (LDG) and Coke Oven Gas (COG) are treated in the inflammable gas pipes and storages. Their major components are carbon monoxide and hydrogen gas that vary in explosion in the ranges of $18 \sim 75 \%$ and $5 \sim 28.4 \%$ respectfully. Thus, by considering such environmental conditions in POSCO, the level of risk for secondary damage significantly increases when a vapor explosion occurs.

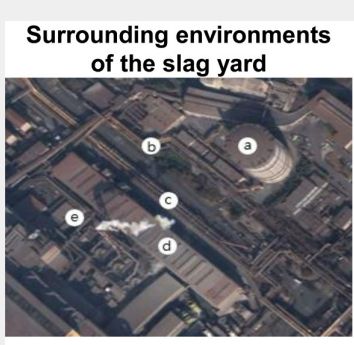

(c)

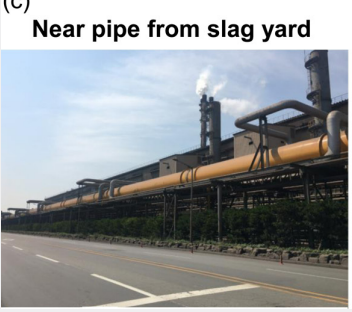

(a)

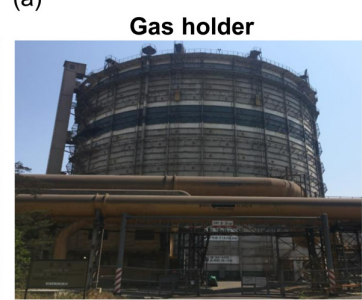

(d)

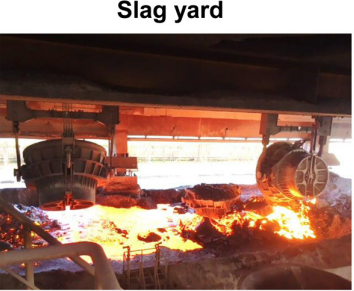

(b)

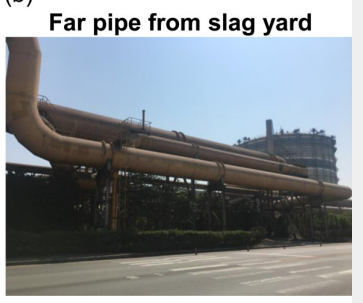

(e)

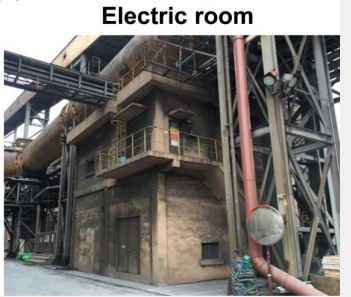

Figure 4: Surrounding environments of the slag yard.

Table 1: Spatial information of slag yard surrounding.

\begin{tabular}{|c|c|c|c|c|}
\hline List & Faculty Name & Main Content & Components & Properties \\
\hline (a) & Gas holder & \multirow[b]{2}{*}{ LDG } & $\mathrm{CO}(60 \%-65 \%)$ & \multirow{2}{*}{$\begin{array}{l}\text { Explosion limit }(18 \%-75 \%) \text {, } \\
\text { Heating value }\left(2000 \mathrm{kcal} / \mathrm{Nm}^{3}\right)\end{array}$} \\
\hline (b) & $\begin{array}{l}\text { Far pipe from slag } \\
\text { yard }\end{array}$ & & $\mathrm{H}_{2}(0 \%-2 \%), \mathrm{N}_{2}(20 \%-22 \%), \mathrm{CO}_{2}(16 \%-18 \%)$ & \\
\hline (c) & $\begin{array}{l}\text { Near pipe from slag } \\
\text { yard }\end{array}$ & COG & $\begin{array}{c}\mathrm{CO}(7 \%-8 \%), \mathrm{H}_{2}(56 \%-58 \%), \mathrm{N}_{2}(1.5 \%), \mathrm{CO}_{2}(2.4 \%-3 \%) \\
\mathrm{CH}_{4}(25 \%-26 \%), \mathrm{C}_{2} \mathrm{H}_{2}(2.2 \%-5.2 \%)\end{array}$ & $\begin{array}{l}\text { Explosion limit }(5 \%-28.4 \%) \text {, } \\
\text { Heating value }\left(4400 \mathrm{kcal} / \mathrm{Nm}^{3}\right)\end{array}$ \\
\hline (d) & Slag yard & Molten slag & $\mathrm{CaO}, \mathrm{Fe}_{2} \mathrm{O}_{3}, \mathrm{MgO}$, etc. & - \\
\hline (e) & Electric room & $\begin{array}{l}\text { Electricity-re- } \\
\text { lated facilities }\end{array}$ & Cable panel & - \\
\hline
\end{tabular}

\section{Manufacturing experiment equipment}

In Figure 5, the experimental equipment was mainly divided into a melted material feeding crucible where molten metal was dropped in a round droplet state, a reaction water tank in which melted material and coolant cause vapor explosions and a water tank that controlled the temperature of the coolant was used to measure the temperature of the molten slag in the water tank. In 
addition, 900W lights were installed on the side of the reaction tank to add light volume during high-speed shooting. The thermal emissivity of the imaging camera was adjusted to 0.4 , considering the transmissivity of the coolant and the high heat molten slag temperature. The square shaped reaction tank (L: $25 \mathrm{~cm}, \mathrm{~W}: 25 \mathrm{~cm}$ and D: $60 \mathrm{~cm}$ ) with a $15-\mathrm{mm}$-thick polycarbonate was installed considering the explosion risks. The tank was designed to maintain about $20 \mathrm{~cm}$ of free fall distance, assuming that the cooling water height was $40 \sim 45 \mathrm{~cm}$. The melted material feeding crucible was designed as a double crucible to allow droplets from the molten slags to be fed into the reaction tank, maintaining a constant diameter of $10 \mathrm{~mm}$. Moreover, considering the on-site conditions, it was designed in such a way that only the first droplet is dropped in a round shape, while additional droplets can be freely dropped in different shapes.

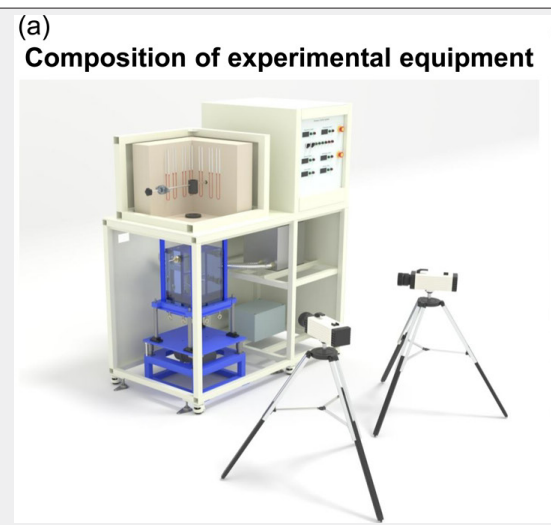

(b)

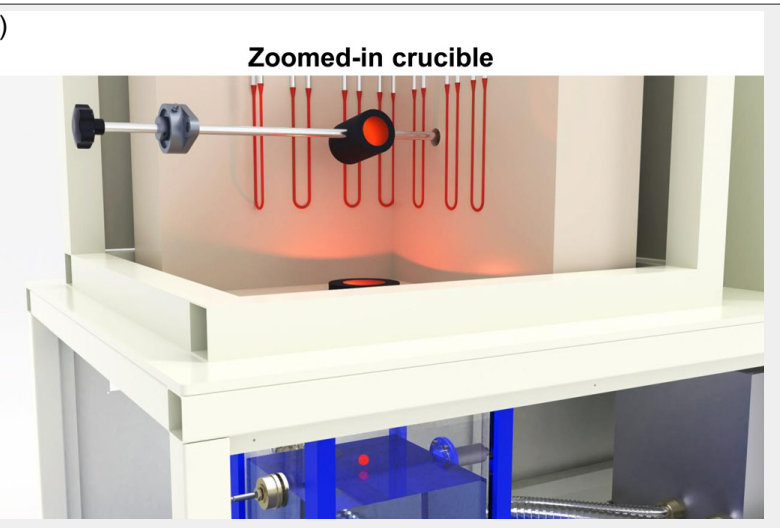

Figure 5: Vapor explosion experiment simulation device.

\section{Results and Discussion}

This study focused on the fundamental research used to examine scientific causes of vapor explosions in slag yards of steelworks using the method shown in Figure 6. First, a slag yard in POSCO in Korea was selected for analyzing the current state of steelworks slag yard and then the spatial information, working process, and components of slag were analyzed. Specific attempts were made to establish an experiment plan and manufacture experiment equipment based on the analysis results.

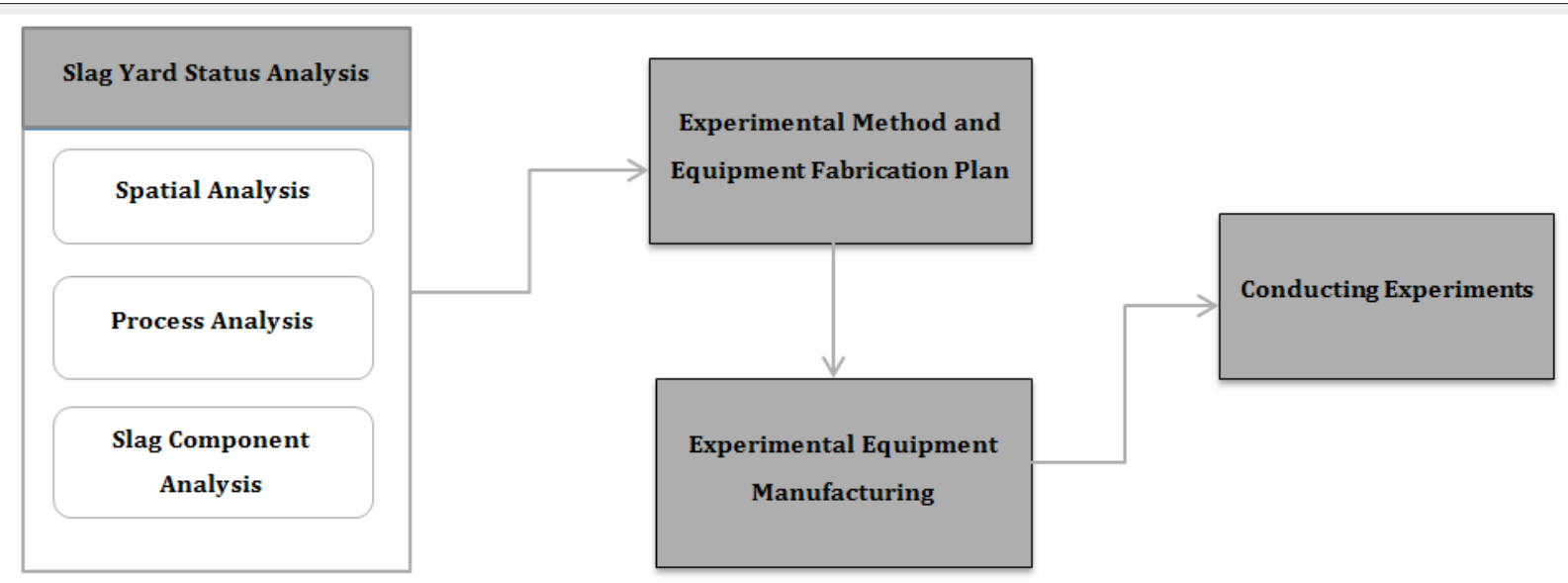

Figure 6: Research method for analysis of slag yard status analysis.

\section{Analysis of the slag yard process}

The slag yard process consists of three phases: skimming, cooling, and loading. Figure 7 shows each phase sequentially progressed for 8 hours. In the skimming process, slag was poured in a yard with no excess water resulting in fewer explosion risks, as shown in Figure 8. The average skimming time is about $1 \mathrm{~min}$ and 19s per process and the maximum and minimum temperatures of the molten slag were about $1500^{\circ} \mathrm{C}$ and $1170^{\circ} \mathrm{C}$ respectively when measured using a thermal imaging camera after applying emissivity of 0.8 . Slag is skimmed at least 60 times during the 8 hours of the skimming process and the resulting skimmed slag was found to be about 1800 tons. After going through the 
skimming process, its surface temperature was about $1,350^{\circ} \mathrm{C}$ due to the natural cooling in air. Then, through an unstable and dangerous procedure, workers operated nozzles manually for the first water injection cooling, as shown in Figure 9. A significant point to be noted is that the workers poured water by using the bar-type water injection instead of the fog-type water injection, allowing cooling water to flow directly into the high-temperature molten slag that ultimately caused vapor explosions to occur due to the expansion of fluid volume. (a)

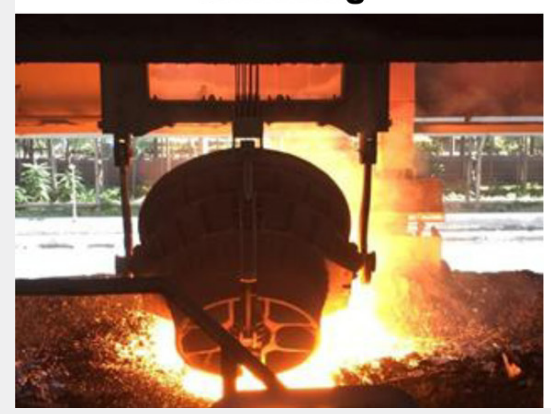

(b)

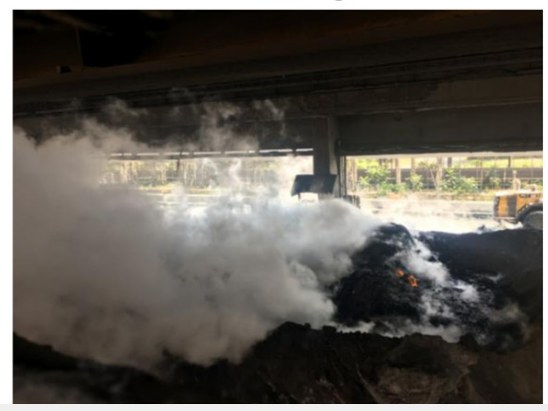

(c)

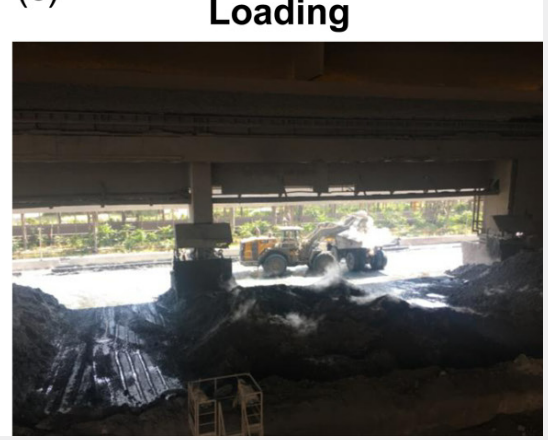

Figure 7: Working process of slag yard.
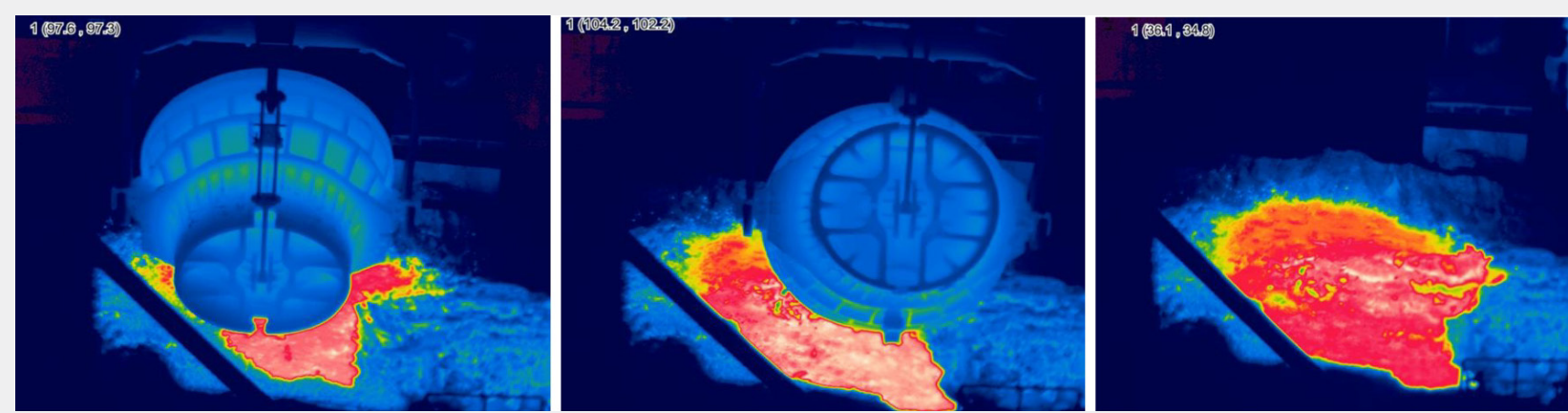

Figure 8: Skimming of slag.
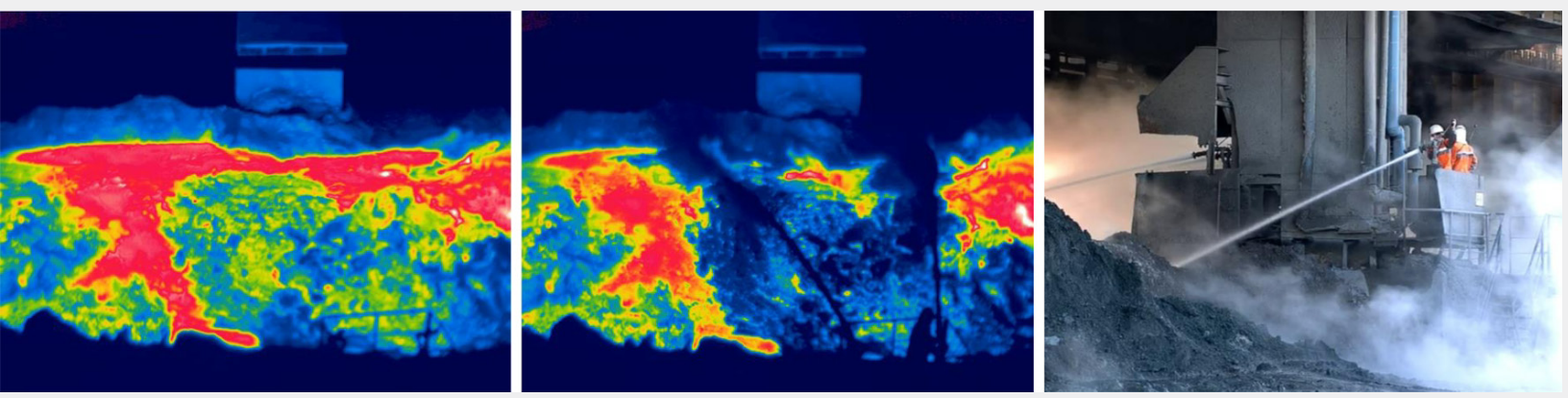

Figure 9: The early cooling operation after skimming.

Due to the repeated cooling process, the temperature of the surface, which was set at $1350^{\circ} \mathrm{C}$, cooled down to about $120^{\circ} \mathrm{C}$ after 4 hours. However, due to the bar-type water injection, cooling dead zones were observed and after the cooling operation, the maximum and minimum slag surface temperatures were $94^{\circ} \mathrm{C}$ and $20^{\circ} \mathrm{C}$ respectively, as shown in Figure 10 . The loading operation is a process that disposes cooled slag after the cooling process is completed. Before a loading operation, slag is mixed using heavy equipment to cool the core of the slag evenly. The temperature of slag was about $20^{\circ} \mathrm{C}$ when the cooling process was completed and then its maximum core temperature was measured to be $543^{\circ} \mathrm{C}$ when loaded using heavy equipment, as shown in Figure 11. At 
that point, high-temperature slag was observed to drop to the ground, which indicates that an unconfined vapor explosion could have occurred if there had been any remaining cooling water stagnant on the ground. Moreover, the risk of vapor explosions could be increased by vibrations caused by the movements of heavy equipment that destroy the boiling film. (a)

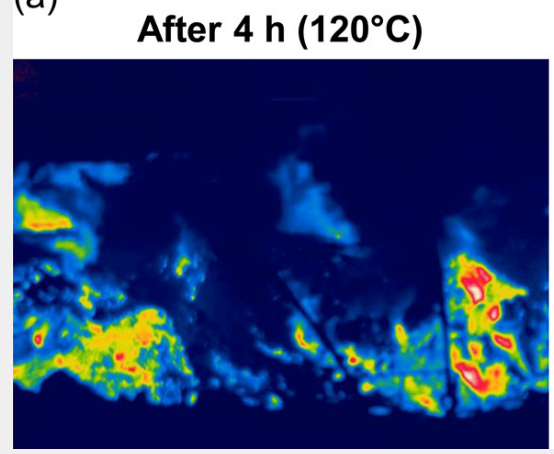

(b)

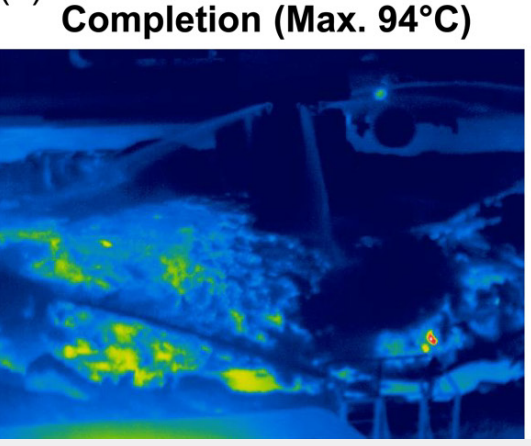

(c) Completion (Min. $20^{\circ} \mathrm{C}$ )

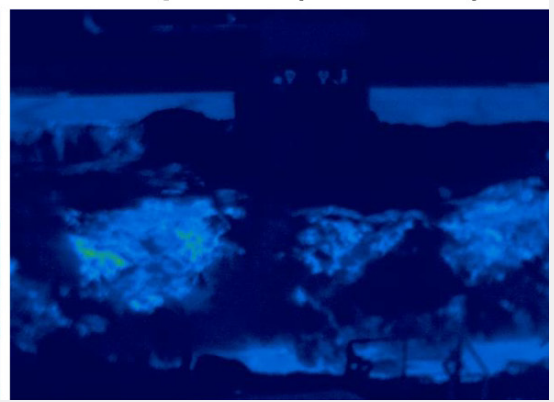

Figure 10: The surface temperature after $4 \mathrm{~h}$ of cooling and after the completion of cooling operation.
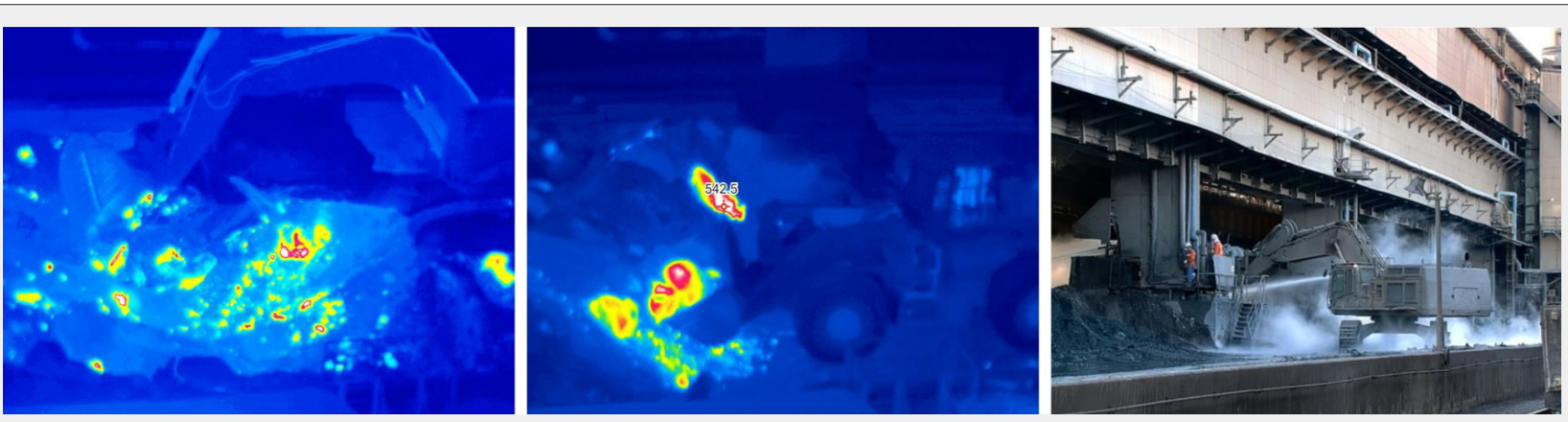

Figure 11: The first loading operation after skimming and cooling operations.

\section{Analysis of the slag yard components}

This research collected and reanalyzed the molten slag that was in the process of on-site cooling. The results showed that steelworks slag is composed of 10 compound oxides and their relevant components as shown in Table 2.

Table 2: Component proportions of slag.

\begin{tabular}{|c|c|c|c|c|}
\hline $\mathbf{S i O}_{2}$ & $\mathbf{A l}_{2} \mathbf{O}_{3}$ & $\mathbf{C a O}$ & $\mathbf{M g O}$ & $\mathbf{F e}_{2} \mathbf{O}_{3}$ \\
\hline $11.92 \%$ & $2.01 \%$ & $70.30 \%$ & $2.02 \%$ & $11.65 \%$ \\
\hline $\mathbf{T i O}_{2}$ & $\mathbf{P}_{2} \mathbf{O}_{5}$ & $\mathbf{M n O}$ & $\mathbf{C r}_{2} \mathbf{O}_{3}$ & $\mathbf{K}_{2} \mathbf{0}$ \\
\hline $0.70 \%$ & $0.60 \%$ & $0.70 \%$ & $0.05 \%$ & $0.05 \%$ \\
\hline
\end{tabular}

The cooling water used for slag cooling was not normal tap water, but fresh water. The water used for cooling was reused water collected after being used for cooling; thus, the study analyzed the water assuming that there would be some changes to its properties or temperature. Three types of the coolant such as tap water, fresh water and yard cooling water were analyzed as shown in Table 3.

The property analysis showed that the yard cooling water had about 50 times higher salinity than general tap water, and its electrical conductivity was also 40 times higher than that of tap water. The reason for the high concentration of salt in the cooling water was due to the seawater desalination. According to Takahiro Arai, salinity had a significant effect on spontaneous vapor explosion; thus, this study considered that comparative experiments should be conducted on three types of cooling water [8]. The eight nozzles that spray water for cooling were 2.56 inches in diameter and $2,160 \mathrm{~m}^{3}$ of coolant was injected per hour. Since a large amount of cooling water was injected, the cooling water circulation method was selected to reduce its cost and because 
the water flowed into the water tank through hot-temperature slag surface, the base temperature of the nozzle-sprayed water or stagnant water was relatively high. Upon measuring the water temperature using a thermal imaging camera, the average water temperature and the maximum temperature were measured to be $48^{\circ} \mathrm{C}$ and $58^{\circ} \mathrm{C}$, respectively (Figure 12 ). According to the Dullforce group, the temperature of cooling water played a significant role in spontaneously destroying the boiling film formed on the surface of the molten metal; thus, the study tried to reflect this fact in the experimental planning [6]. (a)
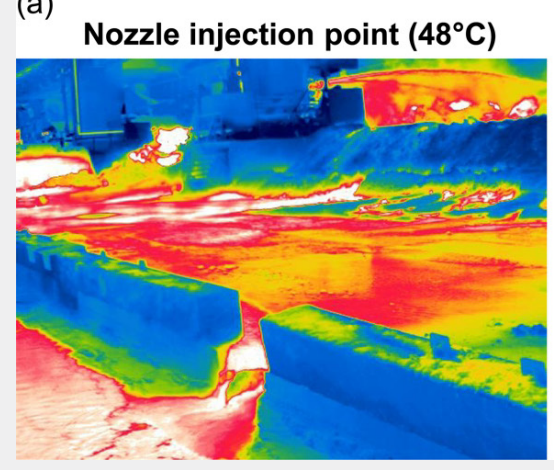

(b)

Mid-section of water $\operatorname{tank}\left(50^{\circ} \mathrm{C}\right)$

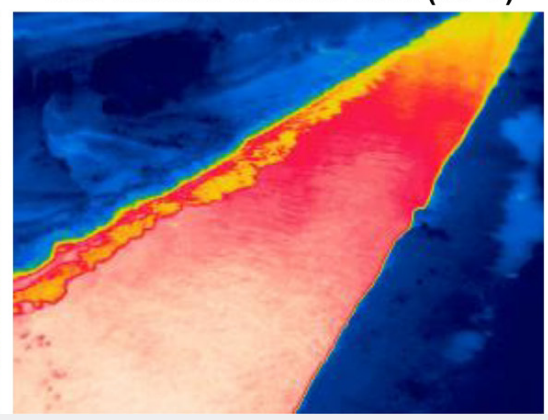

(c) Final section of water $\operatorname{tank}\left(58^{\circ} \mathrm{C}\right)$

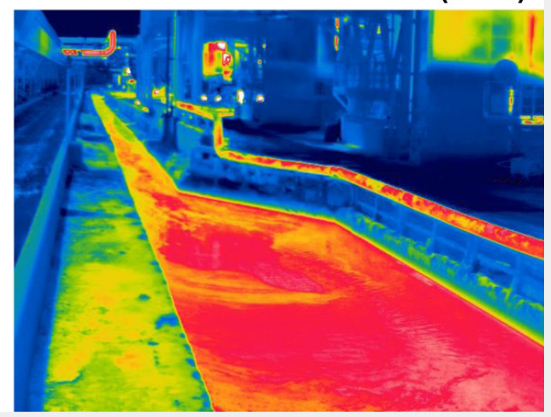

Figure 12: Cooling water nozzle injection and water temperature by inflowing point of water tank.

Table 3: The salinity of three types of cooling water.

\begin{tabular}{|c|c|c|c|c|}
\hline Analysis Item & Unit & Yaad Cooling Water & General Fresh Water & General Tap water \\
\hline Salinity & $\mathrm{psu}$ & 3.8 & 0.3 & 0.1 \\
\hline $\mathrm{Cl}$ ion & $\mathrm{mg} / \mathrm{L}$ & 86 & 63 & 10 \\
\hline
\end{tabular}

Experimental results of the molten slag and three types of cooling water are shown in Figure 13. (O) symbol refers to vapor explosion, while $(\mathrm{X})$ symbol refers to no explosion. The experiment with the reactions based on the temperature change of the three types of cooling water and molten slag showed that spontaneous vapor explosions did not occur with factory fresh water and general tap water [8-10]. However, spontaneous vapor explosions occurred only with yard cooling water at $50^{\circ} \mathrm{C}$, which is used in the field. In the temperature range of $20^{\circ} \mathrm{C}-30^{\circ} \mathrm{C}$ of the cooling water, the molten slag became solid immediately and sank flat right after falling into the water tank. When the temperature of cooling water was over $60^{\circ} \mathrm{C}$, the formation of boiling film was stable. The molten slag maintained high temperatures until it reached the bottom, and explosions did not occur as the boiling film was stable. In the range of $40^{\circ} \mathrm{C}-50^{\circ} \mathrm{C}$, explosive combustion was observed inside of the boiling film, but it was not a spontaneous force that broke the boiling film. However, vapor explosions occurred only when using yard cooling water at $50^{\circ} \mathrm{C}$ with higher salt concentrations. In this experiment, we aimed to observe with the naked eye the propagation and expansion phase of the four phases of vapor explosions; thus, we dropped the various sized molten slag droplets following the first round-shaped droplet. The result showed that when the first slag droplet exploded near the bottom of the water tank, the other slag's boiling films broke due to the generated shock wave, leading to a chain explosion.
The temperature of the molten slag that caused the explosion was the same as the on-site skimming temperature of $1490^{\circ} \mathrm{C}$, and then it decreased to $1410^{\circ} \mathrm{C}$ when reaching the surface of cooling water. Then, its temperature decreased to $1240^{\circ} \mathrm{C}$ when making complete contact with cooling water. Moreover, the temperature was estimated to be $1090^{\circ} \mathrm{C}$ when it was divided into a variety of chunks and made a downward drop of $30 \mathrm{~cm}$. Then, the boiling film was destroyed, and a series of explosions occurred at $30 \mathrm{~cm}$ from the bottom of the water tank.

As shown in Figure 14, the analysis of the debris after the vapor explosion showed that the slag was pulverized into a powder form instead of chunks at the $50^{\circ} \mathrm{C}$ interval of cooling water where a vapor explosion occurred, and in cases of fresh water and tap water, the crater-shaped holes were found on the residues due to the combustion reaction. As shown in Table 4, it was found that $\mathrm{CaO}$ was significantly reduced to about $17 \%$ in comparison to the other components after the analysis of the vapor explosion. It was confirmed that the significant decrease in the $\mathrm{CaO}$ component ratio was because the calcium component of $\mathrm{CaO}$ formed $\mathrm{CaCl}_{2}$ due to the exothermic reaction along with the salinity in yard cooling water. It was determined that the increase in the $\mathrm{Fe}_{2} \mathrm{O}_{3}$ component ratio was beyond the purpose and scope of this study; thus, further research and verification efforts seem to be required. 
(a)

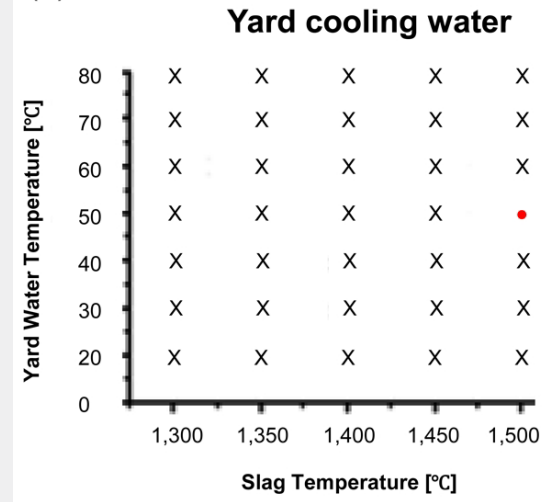

(b)

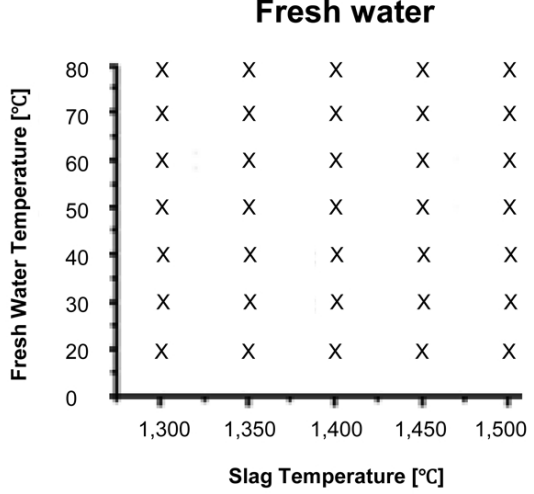

(c)

\begin{tabular}{|c|c|c|c|c|c|}
\hline & & \multicolumn{4}{|c|}{ lap water } \\
\hline 80 & $x$ & $x$ & $x$ & $x$ & $x$ \\
\hline 70 & $x$ & $x$ & $x$ & $x$ & $x$ \\
\hline 60 & $x$ & $x$ & $x$ & $x$ & $x$ \\
\hline 50 & $x$ & $x$ & $x$ & $x$ & $x$ \\
\hline 40 & $x$ & $x$ & $x$ & $x$ & $x$ \\
\hline 30 & $x$ & $x$ & $x$ & $x$ & \\
\hline 20 & $x$ & $x$ & $x$ & $x$ & $x$ \\
\hline 0 & 1,300 & 1,350 & 1,400 & 1,450 & 1,500 \\
\hline
\end{tabular}

Figure 13: Experimental results of the molten slag vapor explosion.

(a)

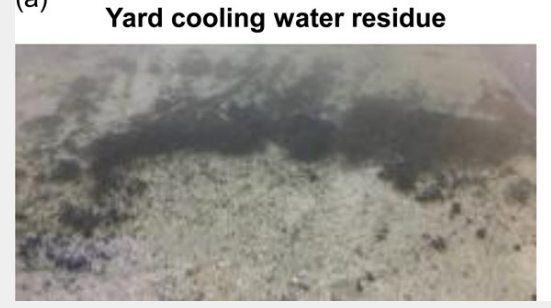

(b)

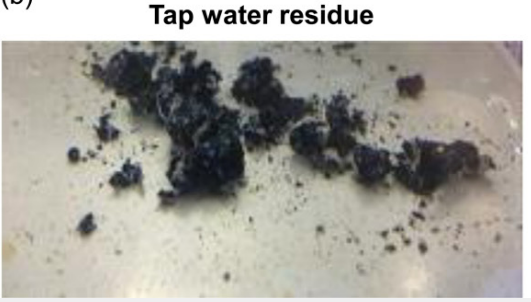

(c)

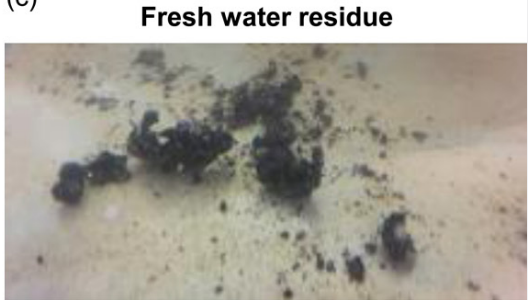

Figure 14: Debris based on the reaction of molten slag to cooling water.

Table 4: Results of the slag components analysis before and after a vapor explosion.

\begin{tabular}{|c|c|c|c|c|c|c|c|c|c|c|}
\hline Class & $\mathbf{S i O}_{2}$ & $\mathbf{A l}_{2} \mathbf{O}_{\mathbf{3}}$ & $\mathbf{C a O}$ & $\mathbf{M g O}$ & $\mathbf{F e}_{2} \mathbf{O}_{3}$ & $\mathbf{T i O}_{2}$ & $\mathbf{P}_{2} \mathbf{O}_{5}$ & $\mathbf{M n O}_{5}$ & $\mathbf{C r}_{2} \mathbf{O}_{3}$ & $\mathbf{K}_{\mathbf{2}} \mathbf{0}$ \\
\hline Before & $11.92 \%$ & $2.01 \%$ & $70.30 \%$ & $2.02 \%$ & $11.65 \%$ & $0.70 \%$ & $0.60 \%$ & $0.70 \%$ & $0.05 \%$ & $0.05 \%$ \\
\hline After & $\begin{array}{c}9.70 \% \\
(\downarrow)\end{array}$ & $\begin{array}{c}1.80 \% \\
(\downarrow)\end{array}$ & $\begin{array}{c}53.01 \% \\
(\downarrow)\end{array}$ & $\begin{array}{c}1.55 \% \\
(\downarrow)\end{array}$ & $\begin{array}{c}32.17 \% \\
(\uparrow)\end{array}$ & $\begin{array}{c}0.62 \% \\
(\downarrow)\end{array}$ & $\begin{array}{c}0.48 \% \\
(\downarrow)\end{array}$ & $\begin{array}{c}0.65 \% \\
(\downarrow)\end{array}$ & $\begin{array}{c}0.01 \% \\
(\downarrow)\end{array}$ & $\begin{array}{c}0.01 \% \\
(\downarrow)\end{array}$ \\
\hline
\end{tabular}

\section{Conclusion}

This study aimed to identify the cause of increasing vapor explosions occurring annually in the slag yard work process in the steel industry. To design an experimental environment similar to the conditions in the field, the study analyzed the current state of slag yards in steelworks, and then established an experimental plan and manufactured experimental equipment based on the analysis results. As a result of conducting the research using small experimental equipment, it was analyzed that the explosion of vapor occurred depending on the characteristics of the work process and coolant in the steel industry.

\section{Work process}

It has been analyzed that vapor explosions may occur in the cooling and loading phases of the slag yard work process. First, the cooling process performed in a bar-type water injection generated dead zones which caused the stagnation of cooling water. It has also been analyzed that the action of dropping not sufficiently cooled molten slag due to on-site vibration and external factors also caused vapor explosions. Though the surface temperature of slag was measured to be about $20^{\circ} \mathrm{C}$ when the cooling process was completed, its internal temperature was measured to be $543^{\circ} \mathrm{C}$ when it was loaded by heavy equipment which resulted in falling chunks of slag. It was found that an unconfined vapor explosion occurred if there was any remaining stagnant cooling water.

\section{Properties of cooling water}

Upon conducting small-scale vapor explosion experiments on yard cooling water, fresh water, and general tap water, spontaneous vapor explosions occurred only at the cooling water temperature of $50{ }^{\circ} \mathrm{C}$. It was observed that the explosion that occurred at $50^{\circ} \mathrm{C}$ of yard cooling water caused a chain explosion delivering a pressure wave to its surrounding slag chunks and destroying the boiling film. The analysis of the molten slag residues generated in 
the experiment showed that the $\mathrm{CaO}$ composition had the most prominent decrease to about $17 \%$, which was due to the reaction of calcium and salinity contained in the yard with $\mathrm{CaCl}_{2}$ causing an exothermic reaction. Thus, it has been verified that the high salinity contained in the coolant causes water vapor explosions. The high concentration of salt in yard cooling water has been analyzed to be the result of the salt concentrated in the process of desalination and cooling of seawater, which was a usual practice in the steel industry. This study was able to identify the scientific causes through basic experimental research on slag yard vapor explosions in the steel industry. Overall, the main cause of the vapor explosion in the steel industry was the coolant $\left(50^{\circ} \mathrm{C}\right)$ containing salt used in slag yards.

Other causes were confirmed to be environmental effects and various conditions that led to human error that could ultimately result in vapor explosions. However, due to the limitations of the study that was conducted, it is necessary to proceed this work to investigate the increase of $\mathrm{Fe}_{2} \mathrm{O}_{3}$ residue of molten slag, which also occurred during the explosion of vapor.

\section{Author Information}

Corresponding authors: Sungyool Bong, Hyoung-Uk Yoon

Author Contributions: Young-Jae Cho and Woojung Park contributed equally to the paper

\section{ORCID}

Young-Jae Cho: 0000-0002-5639-9036.

Woojung Park: 0000-0001-7086-4670.

Hong-Sik Yun: 0000-0002-2104-9423.

Hyoung-Uk Yoon: 0000-0002-5513-5901.

Sungyool Bong: 0000-0003-4270-3882.

\section{Acknowledgment}

This work was supported by the Pohang Iron and Steel Company (POSCO) Research Fund, 2018 (No.2018Z067).

\section{References}

1. Furuya M, Arai T (2019) Effect of Surface Property of Molten Metal Pools on Triggering of Vapor Explosions in Water Droplet Impingement. International Journal of Heat and Mass Transfer 51(17-18): 4439-4446.

2. Abe Y, Nariai H, Hamada Y (2002) The Trigger Mechanism of Vapor Explosion. Journal of Nuclear Science and Technology 39(8): 845853.

3. Berthoud G. (2000) Vapor Explosions. Annu Rev Fluid Mech 32: 573611.

4. Eckhoff RK (2015) Water Vapour Explosions - A Brief Review. Journal of Loss Prevention in the Process Industries 40: 188-198.

5. Matsumura K, Nariai H (1996) Self-Triggering Mechanism of Vapor Explosions for a Molten Tin and Water System. Journal of Nuclear Science and Technology 33(4): 298-306.

6. Dullforce TA, Buchanan DJ, Peckover RS (1976) Self-Triggering of Small-Scale Fuel-Coolant Interactions: I. Experiments. Journal of Physics D: Applied Physics 9(9): 1295-1303.

7. Nelson LS (1995) Steam Explosion Triggering: A Review of Theoretical and Experimental Investigations. Nuclear Engineering and Design 155(1-2): 27-36.

8. Arai T, Furuya M (2007) Effect of Salt Additives to Water on the Severity of Vapor Explosions and on the Collapse of Vapor Film. Thermal Science and Engineering 15(3): 91-100.

9. Furuya M, Kinoshita I (2002) Effects of Polymer, Surfactant, and Salt Additives to a Coolant on the Mitigation and the Severity of Vapor Explosions. Experimental Thermal and Fluid Science 26(2-4): 213-219.

10. Furuya M, Matsumura K, KinoshitaI I (2002) A Linear Stability Analysis of a Vapor Film in Terms of the Triggering of Vapor Explosions. Journal of Nuclear Science and Technology 39(10): 1026-1032.
Your next submission with Juniper Publishers will reach you the below assets

- Quality Editorial service

- Swift Peer Review

- Reprints availability

- E-prints Service

- Manuscript Podcast for convenient understanding

- Global attainment for your research

- Manuscript accessibility in different formats ( Pdf, E-pub, Full Text, Audio)

- Unceasing customer service

Track the below URL for one-step submission https://juniperpublishers.com/online-submission.php 